\title{
ArcheoSciences
}

Revue d'archéométrie

33 (suppl.) | 2009

Mémoire du sol, espace des hommes

\section{First results on the city planning of Cyrrhus (Syria)}

Jeanine Abdul Massih, Christophe Benech and Mathilde Gelin

\section{(2) OpenEdition}

\section{Journals}

Electronic version

URL: https://journals.openedition.org/archeosciences/1584

DOI: 10.4000/archeosciences. 1584

ISBN: 978-2-7535-1599-4

ISSN: 2104-3728

Publisher

Presses universitaires de Rennes

Printed version

Date of publication: 30 October 2009

Number of pages: $201-203$

ISBN: 978-2-7535-0943-6

ISSN: 1960-1360

Electronic reference

Jeanine Abdul Massih, Christophe Benech and Mathilde Gelin, "First results on the city planning of

Cyrrhus (Syria)", ArcheoSciences [Online], 33 (suppl.) | 2009, Online since 30 October 2011, connection on 01 February 2022. URL: http://journals.openedition.org/archeosciences/1584 ; DOI: https://doi.org/ 10.4000/archeosciences.1584 


\title{
First results on the city planning of Cyrrhus (Syria)
}

\author{
Jeanine Abdul Massin *, Christophe Benech ${ }^{* *}$ and Mathilde Gelin ***
}

Keywords: Magnetic survey, Excavations, classical period, city planning, Syria.

The site of Cyrrhus is located in the Afrin valley (North Syria) at the crossing of the roads between Antioch and inner Syria. The layout of the lower town of Cyrrhus is established on a rectangular grid fanning out from the Main Street (Fig. 1). This Hippodamian plan in the pure Hellenistic tradition seems to be more or less respected in the Roman and Byzantine periods. The grid pattern is centred on a colonnaded main street running north/south across the entire city. However, during the Roman period, the town planning is articulated east-west and north-south by the implementation of a new axis for traffic. The streets lead to the major monuments of the site. The $7 \mathrm{~m}$ wide north-south Street paved with basalt serves the Roman theatre located on the slope of the citadel and the Roman military camp at the western edge of the town. In the Byzantine period the grid is respected in regard to its alignment but the buildings encroach on the width of the streets, particularly on the portico of the main road. The Islamic settlement seems to have changed little in the city's layout; but some new discoveries show a completely different organisation and orientation unfortunately unknown till today.

The Lebanese-Syrian Archaeological Mission of Cyrrhus has developed a research project based on the study of the town planning along with the system of fortification. This work on the defenses is being carried out by Shaker Shbib of the DGAMS of Syria and co-director of the excavation team.

Figure 1: Satellite view (Google Earth) from the site of Cyrrhus with the main monuments indicated.

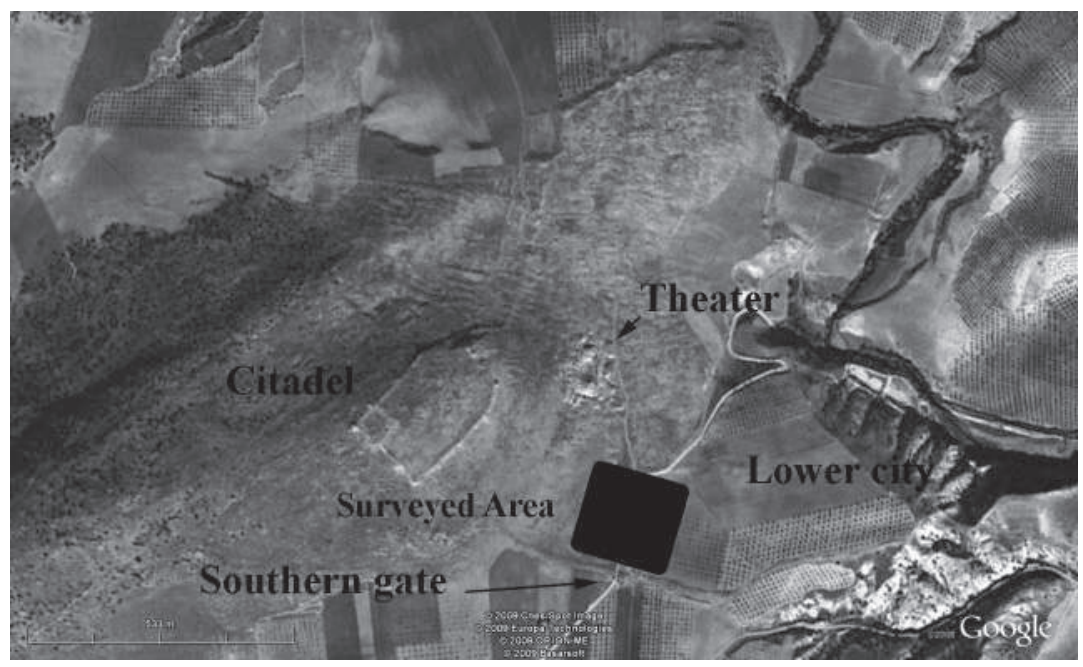

\footnotetext{
* Lebanese University, Beirut.

** UMR 5133 Archeorient, Maison de l'Orient et de la Méditerranée.

*** UMR 7041 Arscan, Maison René Ginouves.
} 
The study of Cyrrhus through geophysical survey is being developed in collaboration with the Project PROGECESA (Geophysical survey and study of ancient urban centers of Syria), financed by the French National Agency of Research. This research concerns the lower city of Cyrrhus which until now has remained almost wholly unknown.

\section{FirST RESUlts}

\section{1) Excavations}

The Lebanese-Syrian Archaeological Mission concentrated its first investigation of the southern fortification on: the citadel, the walls, the towers and the main entrance. The choice of the southern wall was made in parallel with the study of the town planning in this part of the city. The main street is represented by a straight line coming from the northern entrance toward the south. At a point after the theater this street deviates to the south-west and passes through the southern entrance. This variation on the main axe was analyzed and explained by new discoveries on the position of the first fortification on the slope of the acropolis.

\section{The first fortification (Fig. 2)}

A work program has been established on the citadel of Cyrrhus under the supervision of M. Gelin. Work began in

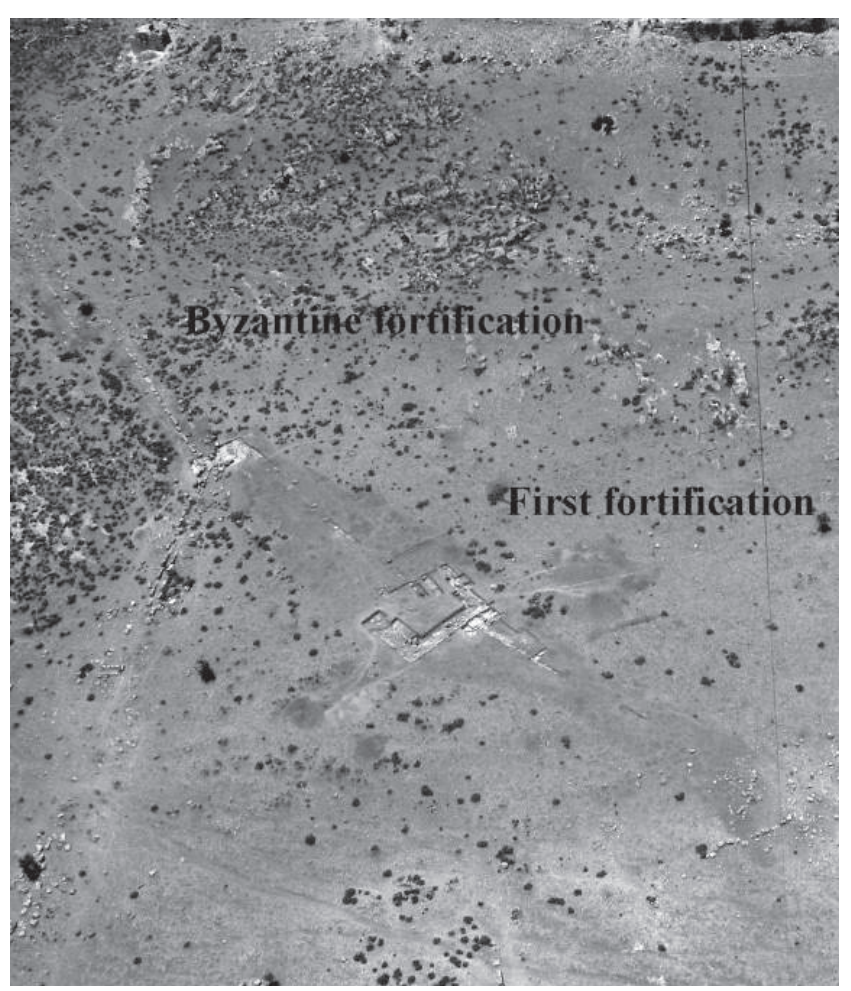

2007 on the south part of the fortress fortifications, with the aim of establishing its complete chronology. A wall built with huge polygonal stones is visible under the medieval fortifications, which represents the first state of occupation.

Inside the fortress, work has been carried out on the façade of a medieval tower and is continuing. The results show that this tower is built on top of a more ancient one, as in the case of the first wall mentioned above. Its construction materials and techniques lead us to think that it was probably built by Greeks. Only further work will confirm or not these results. Several later occupations have been revealed, with domestic structures belonging to the medieval period. It is however surprising that neither Roman nor Byzantine levels has been found.

East of the citadel, on the slope leading to the lower city, we cleaned and revealed the continuation of the socalled Greek rampart, with two towers and the curtain-wall. Unfortunately, the soil had mostly been removed down to bedrock and no stratigraphy subsists, but the wall is linked to the first rampart. It has a different line from the later wall (more oriented to the north) and this discovery is very important for the city's history: it means that the early city, maybe in Greek times, was smaller than the Roman, Byzantine and Medieval ones.

For the next campaign, work will be concentrated on the two towers sector, with the aim of reaching foundation levels in order to date their construction. Other soundings will be opened on the east wall, to establish if the existing citadel had the same plan in antiquity.

\section{2) Magnetic survey (Fig. 3)}

The magnetic survey was carried with a Cesium gradiometer using $0.1 \mathrm{~s}$ acquisition data and $1 \mathrm{~m}$ space between profiles. The survey began in the southern part of the site, where the main north-south street changes direction to reach the southern gate. The first results revealed interesting information about the evolution of the city's layout. The main street is about $19 \mathrm{~m}$ wide and is bordered by small square rooms ( $6 \mathrm{~m}$ each side), which can be identified without doubt as shops. The change of direction of the main street cut through the original plan of the city. This original orientation took into account buildings on the western side of the main street, where one of them clearly shows the ground plan of a church. We find also the same orientation in the buildings of the northern part of the site and also in

Figure 2: Ike view from the excavation of the first fortification of Cyrrhus. To the south, in the left part of the picture, we can follow the layout of the byzantine fortification. 
Figure 3: Magnetic survey on both sides of the main street, just to the North of the southern gate.

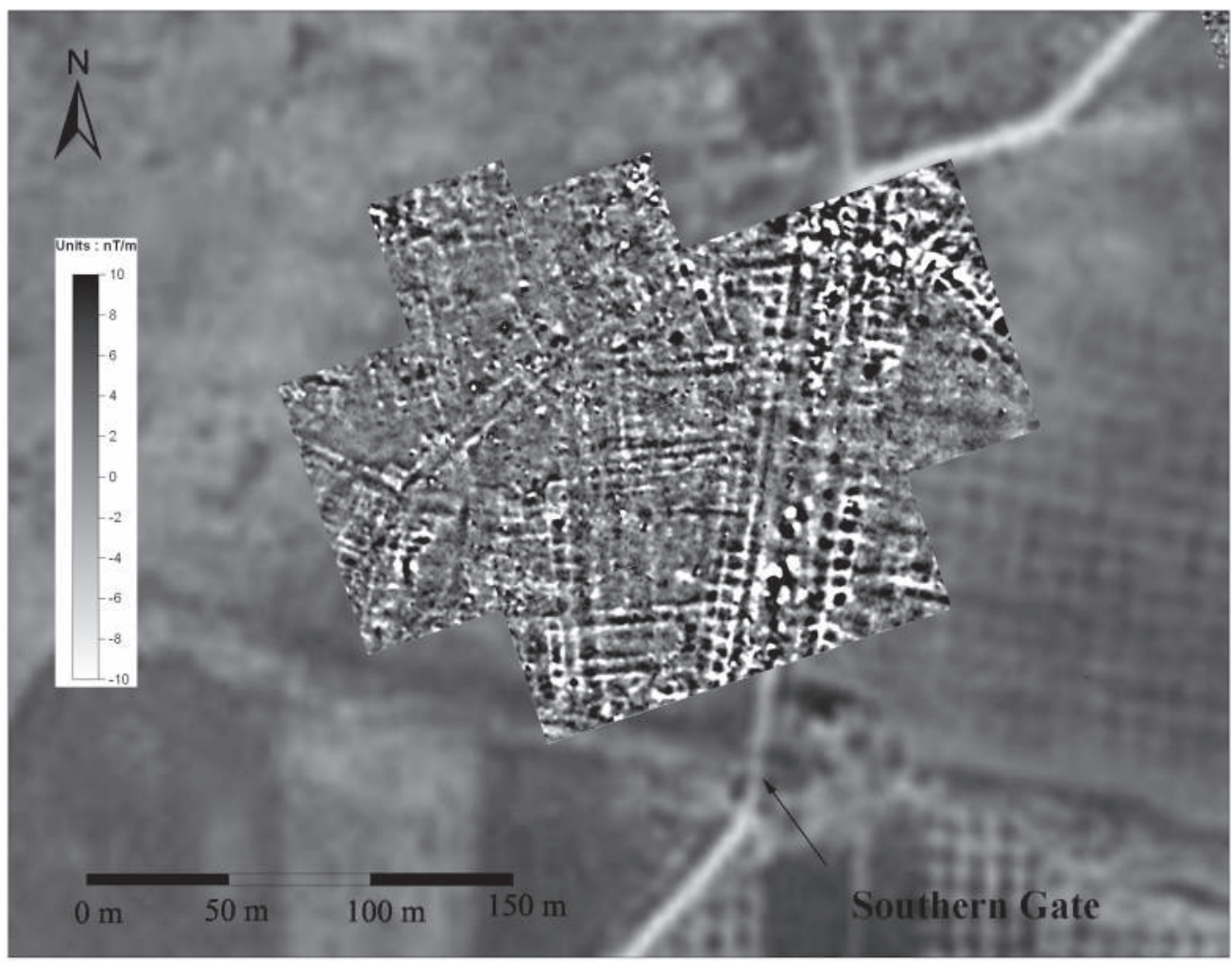

the northern part of the main street. On the eastern side, all the constructions seem to have the same orientation as the main street. In the western part of the magnetic map, we have also a high density of buildings but without specific orientation. At present it is difficult to make a statement about the chronology of this organization in regard to the buildings along the western side of the street. None of these parts seems to override the other. They could be contemporaneous and the difference of orientation might be due to a different organization of the city planning on the slopes of the hill. Moreover, the plan of the buildings is totally different and in the north western corner of the magnetic map, they seem to be surrounded by a wall.

\section{ConClusion}

In further study the limit of the first Hellenistic establishment needs to be identified through archaeological and geophysical survey in order to complete the alignment of the first rampart and to locate the previous southern main entrance of the city. Study of this issue will be completed by the geophysical results on the survey of the entire area between the current limits of the site and the original alignment. This study will expand the research and assist our comprehension of the evolution of the town plan along with the expansion of the city.

\section{Références}

Frezouls, E., 1954-1955. Recherches historiques et archéologiques sur la ville de Cyrrhus, $A A A S$, IV-V: 89-128.

Frezouls, E., 1977. Cyrrhus et la Cyrrhestique jusqu’à la fin du Haut-Empire, $A N R W$, II: 164-197.

Abdul Massin, J. 2006-2007. Évaluation de l'état général du site archéologique de Cyrrhus - Nebi Houri, Annales Archéologiques de Syrie, under press.

Abdul Massin, J. Notes préliminaires sur la fortification polygonale et les mosaïques de la maison romaine de Cyrrhus (Nebi Houri), Syria, under press. 